\title{
SELECTION OF ENVIRONMENTAL TEMPERATURE BY THE YELLOW SCORPION Tityus serrulatus LUTZ \& MELLO, 1922 (SCORPIONES, BUTHIDAE)
}

HOSHINO K. (1), MOURA A. T. V. (1), DE PAULA H. M. G. (1)

(1) Department of Biological Sciences, Faculty of Sciences, São Paulo State University, UNESP, Bauru, São Paulo, Brazil.

ABSTRACT: The preferred temperature of the yellow scorpion Tityus serrulatus was investigated since its dispersion is a matter of concern. Adult $T$. serrulatus, weighing $1.24 \pm 0.20 \mathrm{~g}$ (mean $\pm \mathrm{sd}$ ) and with a standard length of $59.3 \pm 2.5 \mathrm{~mm}$, were used. A metallic corridor (120 cm long, $5 \mathrm{~cm}$ large and $10 \mathrm{~cm}$ high) with thermal gradient ranging from $0^{\circ} \mathrm{C}$ to $40^{\circ} \mathrm{C}$ was used. Tityus serrulatus chose and stayed in temperatures ranging from $14^{\circ} \mathrm{C}$ to $38^{\circ} \mathrm{C}$ when safe conditions were offered (dark and thigmotactic stimuli). The number of animals that remained in the $11^{\circ} \mathrm{C}-20^{\circ} \mathrm{C}$, $21^{\circ} \mathrm{C}-30^{\circ} \mathrm{C}$, and $31^{\circ} \mathrm{C}-40^{\circ} \mathrm{C}$ temperature zones were 8,8 , and 9 , respectively. The chi-square test (degree of freedom $=2$ ) showed that differences were not significant ( $p>0.05)$. Some animals moved to lower temperature areas (less than $8^{\circ} \mathrm{C}$ ) when the corridor was completely illuminated and thigmotactic stimuli were absent, which led the animals to present a torpor state. It is concluded that $T$. serrulatus does not select a specific environmental temperature. Associated with the capacity of temporally surviving at low temperatures, this species seems to be highly adaptable to different thermal zones.

KEY WORDS: Tityus serrulatus, scorpion, temperature, thermal gradient, zoogeography.

\section{CORRESPONDENCE TO:}

KATSUMASA HOSHINO, Departamento Ciências Biológicas, Faculdade de Ciências, Universidade Estadual Paulista (UNESP), 17.033-360, Bauru, SP, Brasil. Phone: +55 143103 6078. Fax: +55 143103 6092. Email: hoshino@fc.unesp.br 


\section{INTRODUCTION}

Scorpions originated approximately 400 millions years ago and were the first arthropods to occupy terrestrial environments; nowadays, they can be found worldwide, except in Antarctica $(9,10)$. The presence of some species in urban areas is a well-known fact. Although many species are reported to be inoffensive for humans (9), their painful bites are frightening due to the mortal venom of few species, like Tityus serrulatus. This species, originated in the state of Minas Gerais, Brazil, shows a progressive dispersion, and its presence is now recorded in the Brazilian southeast, south and middle-west regions. It is responsible for approximately 8,000 cases of accidents per year in Brazil, being lethal in $0.51 \%$ of them, according to the National Center for Epidemiology (Centro Nacional de Epidemiologia) (3).

Studies aimed at assessing the thermoregulatory capacity of scorpions indicate that some species may support hot desert temperatures, others tolerate freezing conditions, whereas many of them survive only in a relatively small range of temperatures from which they select the preferred ones (9). The existence of thermal limits for many scorpion species seems to play a role in their geographical distribution. A detailed recording of the presence of $T$. serrulatus in the state of São Paulo, Brazil, revealed that $T$. serrulatus is absent in the region of Botucatu city, although found in its vicinities (12). The altitude of $800 \mathrm{~m}$ and winter temperatures below $10^{\circ} \mathrm{C}$ could explain the absence of $T$. serrulatus in this area, since episodic falls in the environmental temperature promotes high mortality, as observed with other species of scorpions $(4,9)$.

The present study investigated the limits of temperatures tolerated by $T$. serrulatus as well as its preferred temperatures, since there is no data on the thermoregulatory capacities of the species, nor information on the possible role of the environmental temperature as a natural barrier for its geographical dispersion.

\section{MATERIALS AND METHODS}

Forty-five females of Tityus serrulatus (Lutz and Melo 1922) (Scorpiones, Buthidae), popularly named as yellow scorpion, were used. The mean of their standard size $( \pm$ standard deviation) was $59.3 \pm 2.5 \mathrm{~mm}$, and their mean weight was $1.24 \pm 0.20 \mathrm{~g}$. They were captured and donated by the Municipal Secretariat of Health of Jaú (Secretaria da Saúde de Jaú, São Paulo). The animals were kept in glass cages (40 $\times 20 \times 22.5 \mathrm{~cm}$ ) at a $23^{\circ} \mathrm{C}-26^{\circ} \mathrm{C}$ room with natural light cycles. Tenebrio larvae were 
K. Hoshino et al. SELECTION OF ENVIRONMENTAL TEMPERATURE BY THE YELLOW SCORPION Tityus serrulatus LUTZ \& MELLO, 1922 (SCORPIONES, BUTHIDAE). J. Venom. Anim. Toxins incl. Trop. Dis., 2006, 12,1, p.61

daily offered for feeding. A period of 30 days before their use was allowed for adaptation to captivity.

The thermal limits and the selected temperature range were determined in a metallic corridor $120 \mathrm{~cm}$ long, $5 \mathrm{~cm}$ wide, and $10 \mathrm{~cm}$ high. The corridor was elevated $80 \mathrm{~cm}$ above the ground, held by the extremities on two separated tables. A domestic heater placed nearby one of the corridor's extremity maintained it at $40^{\circ} \mathrm{C}-45^{\circ} \mathrm{C}$ (dependent on the heater distance), whereas the other extremity was maintained at $0^{\circ} \mathrm{C}$ by placing plastic blocks internally filled with ice. The heated and cooled sides were chosen by chance before each session. Observations started only after thermal gradient stability and were carried out in a $23^{\circ} \mathrm{C}-26^{\circ} \mathrm{C}$ temperature-controlled room. The place where the animals were found and the respective temperatures were determined and recorded every 15 minutes in a 2-hour session. All tests were performed between 7 p.m. and 10:30 p.m.

Four pilot studies, using 5 animals each, were initially carried out in order to check the method. The first one was performed to determine the scorpions' preferred place in the corridor, independent of the temperature. The second study was done to observe the selection of the temperature, but the corridor illumination produced by a 120 watts lamp bulb positioned $120 \mathrm{~cm}$ above the apparatus, seemed to affect the results. So, the third study was carried out under a red light of 20 watts placed $50 \mathrm{~cm}$ above the corridor, and this test was made simultaneously in three scorpions (one animal was tested twice). Such modifications in the test conditions tried to overcome the low amount of ambulatory activity recorded in the first and second pilot studies, which suggested the prevalence of anti-predatory defensive behavior. It has been reported that biochemical mediators may affect the thermoregulatory mechanisms of arthropods, leading them to present altered responses related to the temperature behavioral control (5). The existence of similar mediators in scorpions seems possible because some of them are able to tolerate low and high temperatures, as cited before. The long permanence in a fixed place due to defensive behavior may be thought to change the subsequent temperature choice by the release of such metabolic modulating substances. Thus, stimulation of the locomotor activity was tried by testing animals in groups, in order to induce scorpion's contact with different temperatures. It was described in literature that the immobility behavior is more frequently seen in yellow scorpions kept in captivity when they are inaccessible to the contact with peers (6). The last study of this preliminary part was aimed at assessing 
K. Hoshino et al. SELECTION OF ENVIRONMENTAL TEMPERATURE BY THE YELLOW SCORPION Tityus serrulatus LUTZ \& MELLO, 1922 (SCORPIONES, BUTHIDAE). J. Venom. Anim. Toxins incl. Trop. Dis., 2006, 12,1, p.62

the importance of thigmotactic stimuli on the temperature choice behavior. For this, a wooden board (100 cm long, $1.5 \mathrm{~cm}$ wide, and $0.6 \mathrm{~cm}$ thick) was fixed $1.5 \mathrm{~cm}$ above the corridor to provide an increase in the apparatus surface providing tactile stimuli. The red light was on in this test.

The main study to determine the preferred temperature used 25 animals, tested in groups of 3 , except for the last one with 4 scorpions. They were placed in the thermal gradient corridor together with the wooden board and the red light on. The preferred temperature was defined as the temperature measured in the site where the animal remained for at least 45 minutes.

The temperature range chosen by the scorpions was divided into zones for analytical purpose. The first zone ranged from $11^{\circ} \mathrm{C}$ to $20^{\circ} \mathrm{C}$, the second from $20^{\circ} \mathrm{C}$ to $30^{\circ} \mathrm{C}$, and the last from $31^{\circ} \mathrm{C}$ to $40^{\circ} \mathrm{C}$. Statistical significance of differences in the animals' distribution along the thermal zones was assessed by the chi-square test ( 2 degrees of freedom) with the significance level set at $5 \%$.

\section{RESULTS}

In the first pilot study, the scorpions showed one or two episodes of locomotor activity, in general, during the initial minutes after their placement in the illuminated corridor. They walked along all the extension of it, presenting lateral body contact with the corridor's wall. Thereafter, they remained immobile until the end of the session, with the caudal portion of the body leaned against the corridor's corner. No particular corner was chosen.

No animal moved towards the heated extremity of the corridor (above $40^{\circ} \mathrm{C}$ ), but some of them walked directly to the cooled region (kept at $0^{\circ} \mathrm{C}$ ) when the corridor was completely illuminated (second pilot study). Three animals stayed in places where the temperature ranged from $31^{\circ} \mathrm{C}$ to $39^{\circ} \mathrm{C}$, whereas two of them remained at temperatures lower than $8^{\circ} \mathrm{C}$. Motor activity in these last animals became progressively slow and uncoordinated, and they were removed completely immobile at the end of observations. They showed to recover movements and natural responses spontaneously when kept at room temperature after a few minutes. Observation of the groups under red light showed an increase in the number of locomotor episodes (more than 4 episodes/animal) and provided the information that no agonistic confrontations are shown, confirming that the place to stay longer is not determined by territorial dispute. Four animals stopped near the corridor's corner at 
K. Hoshino et al. SELECTION OF ENVIRONMENTAL TEMPERATURE BY THE YELLOW SCORPION Tityus serrulatus LUTZ \& MELLO, 1922 (SCORPIONES, BUTHIDAE). J. Venom. Anim. Toxins incl. Trop. Dis., 2006, 12,1, p.63

$39^{\circ} \mathrm{C}$ and one animal stayed at $31^{\circ} \mathrm{C}$ after ceasing locomotor activity. The conditions of the last pilot study showed to better disperse the animals in the remaining places and were considered adequate to be adopted in the main study to access the preferred temperatures.

The main observation indicated that locomotor activity in grouped animals is characterized by slow movements frequently interrupted by returns and activities that resemble exploration. They did not exhibit the relatively rapid episodes of locomotion observed in the first and second observations. The animals become immobile at last, stopping at places where temperature ranged from $14^{\circ} \mathrm{C}$ to $38^{\circ} \mathrm{C}$. The frequency of animals that preferred to stay in the thermal zones of the gradient corridor is presented in Figure 1. The chi-square test did not reveal significant differences in the number of animals that chose the three different ranges of temperatures in the corridor.

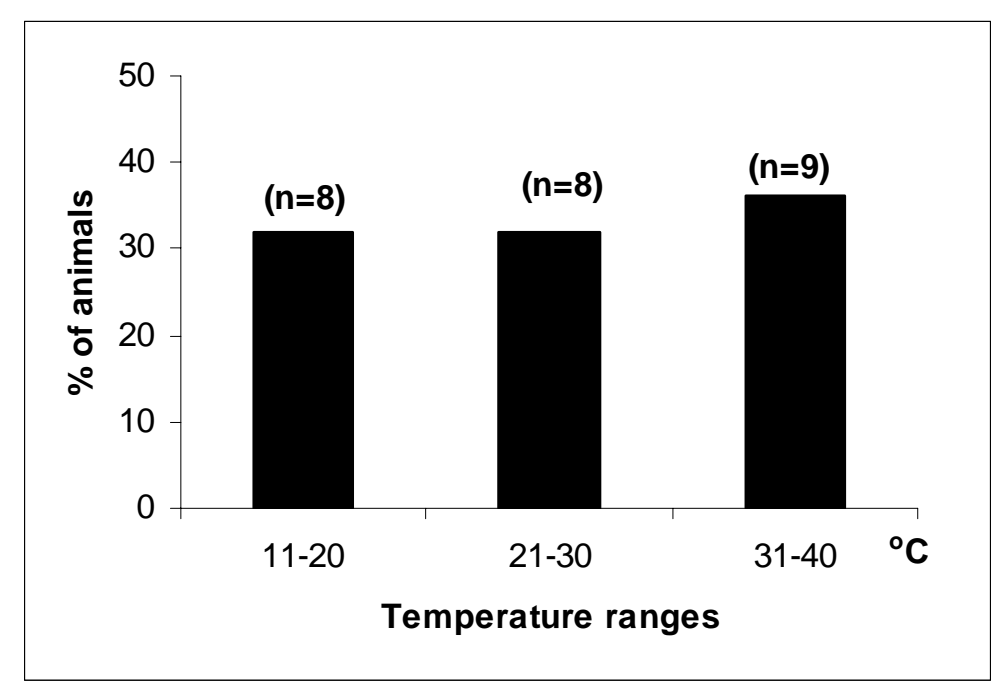

Figure 1. Distribution of yellow scorpion (Tityus serrulatus) individuals along the three thermal ranges (from $10^{\circ} \mathrm{C}$ to $41^{\circ} \mathrm{C}$ ) zones. Differences are not statistically significant according to the Chi-square test $(\mathrm{df}=2 ; p>0.05)$.

\section{DISCUSSION}

The results obtained in the present study indicate that $T$. serrulatus tolerates temperatures between the lower limit of approximately $14^{\circ} \mathrm{C}$ and the upper limit of $38^{\circ} \mathrm{C}$. These temperatures do not seem to be biased by the short time of observation compared to studies in which the time allowed for the temperature choice lasted one day (10). Short sessions of observation were used also by Warbourg and Ben-Horin 
K. Hoshino et al. SELECTION OF ENVIRONMENTAL TEMPERATURE BY THE YELLOW SCORPION Tityus serrulatus LUTZ \& MELLO, 1922 (SCORPIONES, BUTHIDAE). J. Venom. Anim. Toxins incl. Trop. Dis., 2006, 12, 1, p.64

(1981) to evaluate the preferred temperature of Ottentotta judaica and Leiurus quinquestriatus (13). The absence of bias seems to be confirmed by the similarity between the thermal zone determined for the yellow scorpion and that observed for Leiurus quinquestriatus, which ranges from $15^{\circ} \mathrm{C}$ to $39^{\circ} \mathrm{C}$ (1). The range of temperatures chosen by $T$. serrulatus is larger than those observed for Opistophtalmus latimanus (2), Heterometrus petersii pertersii (8), Nemo hierichontichus, and Scorpio murus fuscus (13), which prefer temperature ranges between $32^{\circ} \mathrm{C}-38^{\circ} \mathrm{C}, 34^{\circ} \mathrm{C}-35^{\circ} \mathrm{C}, 23^{\circ} \mathrm{C}-25^{\circ} \mathrm{C}$, and $23^{\circ} \mathrm{C}-25^{\circ} \mathrm{C}$, respectively.

The limits of temperatures chosen by $T$. serrulatus, determined in the present study, are supported by our parallel study that monitored their cardiac activity in different temperatures (7). A cardiac cycle recorded in the electrocardiogram is composed by a spike activity (probably the neurogenic potentials), followed by a slow wave (myogenic depolarization and repolarization). These waves are repeated with great uniformity in frequency and amplitude if the animal remains undisturbed. Heart rate at $12^{\circ} \mathrm{C}-14^{\circ} \mathrm{C}$ shows a mean of 41 and 155 beats/min at $36^{\circ} \mathrm{C}-38^{\circ} \mathrm{C}$, with a mean increase of 5 beats $/ \mathrm{min} /{ }^{\circ} \mathrm{C}$. The linearity in the heart rate is lost in temperatures below $12^{\circ} \mathrm{C}$ and above $38^{\circ} \mathrm{C}$, and the permanence in these temperatures leads to the disappearance of slow-waves followed by the spike activity suppression. These data confirm that the thermal limits determined by the behavioral method in the present study is correct, whereas electrocardiographic data indicate that behavioral selection of temperatures is limited by physiological disarrangements. It is additionally interesting that heart rates were slightly higher when the environmental temperature was gradually lowered, compared to the rates observed when the temperature was increased in similar velocities. Such observation suggests the existence of neurohormones that modulate the metabolic activity and thermoregulation.

The observation that $T$. serrulatus resists low temperatures, at least temporarily, in a torpor state is not unexpected. Many species have adaptive processes to survive in low temperatures (9). Such property in $T$. serrulatus, associated to its large range of temperatures choice, indicates that most temperature fluctuations observed in subtropical zones may not be posited as a natural barrier for the geographical dispersion of the species. Such conclusion leads to a new explanation for the absence of this species in the region of Botucatu city, mentioned before. Identification 
K. Hoshino et al. SELECTION OF ENVIRONMENTAL TEMPERATURE BY THE YELLOW SCORPION Tityus serrulatus LUTZ \& MELLO, 1922 (SCORPIONES, BUTHIDAE). J. Venom. Anim. Toxins incl. Trop. Dis., 2006, 12,1, p. 65

of the scorpions captured in the region started after the end of the present study, and showed the presence of $T$. serrulatus (reported by C. Lenneberg-Hoshino in 2003). Consequently, absence of this species in the considered region (12) seems to derive from the lack of notification to sanitary authorities or due to a more recent introduction of the species into the area.

Observation that part of the scorpions remained at temperatures lower than $8^{\circ} \mathrm{C}$ when the whole corridor was illuminated indicates that their capacity to survive in such condition might be used when the prioritization of defensive responses is demanded. The photophobic behavior of scorpions is well documented $(1,11,14)$, and photophobia in many animal species prevents their exposition to open places where detection by predators is facilitated. The thigmotactic behavior observed in the preliminary studies confirms the high priority of defensive behaviors. Such priority seems to explain the lower number of locomotor episodes when the animal was tested alone.

Finally, we conclude that the yellow scorpion Tityus serrulatus does not have a specific preferred temperature between $14^{\circ} \mathrm{C}$ and $38^{\circ} \mathrm{C}$ and may even tolerate temperatures below $8^{\circ} \mathrm{C}$ in a torpor state. This fact suggests that the species is highly adaptable to different thermal zones.

\section{REFERENCES}

1 ABUSHAMA FT. On the behavior and sensory physiology of the scorpion Leiurus quinquestriatus. Anim. Behav., 1964, 12, 140-53.

2 ALEXANDER AJ., EWER DW. Temperature adaptive behaviour in the scorpion Opisthophthalmus latimanus. J. Exp. Biol., 1958, 35, 349-59.

3 BRASIL. Ministério da Saúde. Fundação Nacional de Saúde. Centro Nacional de Epidemiologia. Acidentes por animais peçonhentos. In: Guia brasileiro de vigilância epidemiológica. 5.ed. Brasília, 1998: 1-12.

4 CRAWFORD CS., RIDDLE WA. Cold hardness in centipedes and scorpions in New Mexico. Oikos, 1974, 25, 86-92.

5 McCLAIN E., MAGNUSON P., WARNER SJ. Behavioural fever in a Namib Desert Tenebrionid Beetle, Onymacris plana. J. Insect Physiol., 1988, 34, 279-84. 
K. Hoshino et al. SELECTION OF ENVIRONMENTAL TEMPERATURE BY THE YELLOW SCORPION Tityus serrulatus LUTZ \& MELLO, 1922 (SCORPIONES, BUTHIDAE). J. Venom. Anim. Toxins incl. Trop. Dis., 2006, 12,1, p.66

6 MINEO MF, ASSIS GAF., DEL-CLARO K. Repertório comportamental do escorpião amarelo Tityus serrulatus Lutz \& Mello, 1922 (Scorpiones, Buthidae) em cativeiro. Rev. Bras. Zoociências, 2003, 5, 23-31.

7 MOURA ATV., DE PAULA HMG., HOSHINO K. Avaliação eletrocardiográfica das manifestações comportamentais do escorpião amarelo Tityus serrulatus induzidas por diferentes temperaturas ambientais. Rev. Etol., 2003, 5, 103-9.

8 NEMENZ H., GRUBER J. Experimente und Beobachtungen an Heterometrus longimanus petersii (Thorell) (Scorpiones). Verh. Zool. Bot. Ges. Wien, 1967, 107, 5-24.

9 POLIS GA. The Biology of Scorpions. Stanford: Stanford University Press, 1990. $475 p$.

10 RUPPERT EE., BARNES RD. Invertebrate Zoology. 6.ed. Philadelphia: Saunders Coll. Pub., 1994. 1056p.

11 TORRES F., HEATWOLE $H$. Orientation of some scorpions and tailless whipscorpions. Z. Tierpsychol., 1967, 24, 546-57.

12 VON EICKSTEDT VRD., RIBEIRO LA., CANDIDO DM., ALBUQUERQUE MJ., JORGE MT. Evolution of scorpionism by Tityus bahiensis (Perty) and Tityus serrulatus (Lutz e Mello) and geographical distribution of the two species in the state of São Paulo. J. Venom. Anim. Toxins, 1996, 2, 92-105.

13 WARBURG MR., BEN-HORIN A. The response to temperature gradients of scorpions from mesic and xeric habitats. Comp. Biochem. Physiol. A, 1981, 68, 277-9.

14 WARBURG MR., POLIS GA. Neurobiology. In: POLIS GA. Ed. The Biology of Scorpions. Stanford: Stanford University Press, 1990: 341-413. 